\title{
Legislative Gridlock, Executive Unilateralism, and Policy Governance: The Implications of U.S. Nuclear Power Policymaking for Korean Politics
}

\author{
Seong-Ho Lim
}

How do U.S. administrations occasionally achieve significant policy progress and sustain policy governance despite the usual political turmoil that seemingly bogs down the legislative process? This paper answers this question theoretically, takes an empirical look into U.S. nuclear power policy as an illustrating case, and draws comparative implications for South Korean politics. The theoretical rationale employed here suggests that political conflicts and legislative gridlock motivate the president and administrative actors to bypass the legislative process and unilaterally resort to the use of executive tools in pursuing their policy agendas. Neither able to lead by themselves nor willing to take the blame for policy failures, calculating lawmakers would condone executive unilateralism by strategically acquiescing and would try for rent-seeking by ex post facto oversight. This theoretical rationale is supported by an inquiry into executive-legislative relations with respect to U.S. nuclear power policymaking. Comparatively, however, South Korean politics features no such dual presence of executive unilateralism and strategic condoning by the legislature, consequently suffering chronic woes regarding policy governance. The difference between the two countries is explained in terms of strategic calculations, or a lack thereof, on the part of legislators and executive officials. The presence or absence of these strategic calculations, in turn, depends on the varying degrees of partisan rigidity and the (in)effectiveness of legislative oversight measures.

Key Words: U.S. politics, executive unilateralism, legislative gridlock, policy governance, U.S. nuclear power policymaking, South Korean politics, legislative-executive relations, strategic condoning, legislative oversight

*Seong-Ho Lim(limsh@khu.ac.kr) is a professor in the Department of Political Science, Kyung Hee University, Seoul, Korea. He received a Ph.D. from the Massachusetts Institute of Technology and has worked on a range of issues in legislative, electoral, and party politics from comparative perspectives. He has practical experience with the Korean legislative process, serving as chief of the Korean National Assembly Research Service from 2014 through 2016.

This work was supported by a National Research Foundation of Korea Grant funded by the Korean government (NRF-2013S1A5A2A03046006). The author appreciates the three anonymous reviewers for their highly useful comments. 
Complex and lengthy lawmaking procedures in the U.S. Congress have made the process of passing legislation rough and tumble from the beginning. The U.S. legislative process is filled with confrontations, obstructions, and delays, many of which have political motivations behind them. Intensified partisan conflicts in the new millennium have further exacerbated stalemates in this legislative process. "Legislative gridlock" is now a familiar expression, and annoyingly so.

In contrast to this gloomy picture, however, the American people continue to witness a collection of important policies become newly adopted or heavily revised. These policy breakthroughs have been substantial, though they typically have entailed partisan rhetorical warfare and media uproar. During the Obama presidency, there were significant achievements in fiscal, energy, environmental, immigration, and healthcare policies, to name a few examples. Intriguingly, the executive branch supplied the main fuel for these policies, while the inactive and arguably lethargic Congress seemed to concede the legislative driver's seat. The Trump administration is trying to repeat his predecessor's feat by reversing-or extensively revising-policy directions in tax, trade, law enforcement, business regulation, healthcare, energy, governmental reform, and other policies. To the eyes of casual observers, it has been the executive branch of the U.S. government that has played an active and leading role in policy governance by occasionally managing to make major policy changes.

Whereas political conflicts, attrition warfare, and policy stalemate form a vicious circle in the U.S. legislative process, administrative activism and the occasional substantive breakthrough characterize certain policy areas. The co-presence of these two contrasting sides poses a puzzle. How do U.S. administrations from time to time manage to achieve significant policymaking, or policy changes, and sustain policy governance despite frequent and intense political conflicts and turmoil that seemingly bog down the legislative process?

Answers to these questions are expected to uncover important comparative implications. In some countries such as South Korea, gridlock situations in the legislative process typically coincide with similarly helpless interbranch stalemates and overall governance crises. The Korean president and administrative agencies would surely want to take their own initiatives to achieve certain policy goals but, in recent years, those unilateral attempts have invited unfavorable and even hostile reactions from their legislative counterparts. Deviating from the U.S. case, Korea's executive branch hardly has been credited for major policy progress and has suffered severe governance troubles. This unfortunate situation has unfolded beyond control, especially during the nowdefunct Park Geun-hye presidency. 
Why does the South Korean case feature these kinds of political and policymaking difficulties? South Korea and the United States certainly have many differences, but they also share similarities in fundamental ways: the separation-of-powers principle, a presidential system, first-past-the-post single-member district electoral systems, legislative processes equipped with supermajority rules, and the frequent emergence of divided government. What is more, the two countries are alike in experiencing polarized political battles. Despite these important similarities, the United States boasts of occasional policy breakthroughs led by an active, and often unilateral, executive branch, while the South Korean government significantly lags behind in generating such positive outcomes. What explains the difference between the two countries? This paper assumes that examining the U.S. case in-depth will bring comparative insights that will help answer this question and uncover some clues for more successful policymaking outcomes in Korea.

The following section will establish a two-tier theoretical rationale. First, political conflicts and legislative gridlock motivate the president and administrative actors to bypass the legislative process and unilaterally resort to executive tools in pursuing their policy agenda. Second, neither able to lead by themselves nor willing to take the blame for policy failures, calculating lawmakers often acquiescence in order to strategically condone executive unilateralism and, further, try for rent-seeking through ex post facto oversight. To support this theoretical reasoning, the third section will take an empirical look into U.S. nuclear energy policy as a crucial case.

In the fourth section, the comparative implications drawn from the theoretical and empirical analyses will be discussed. The first subsection will raise normative issues about the ironic interplay between a legislative process mired in political conflicts and the policy governance arena driven by a unilateralacting executive branch. The second subsection will comparatively look into South Korean politics, where partisan fights, unlike in the United States, bog down the whole system of policy governance, especially the legislative process. This contrast between the two countries will be explained in terms of strategic thinking and political calculations, or lack thereof, on the part of legislators and executive actors. Rigid collectivist party disciplines along with ineffective legislative oversight capabilities have prevented Korean politicians from acting strategically, thereby damaging overall policy governance.

This paper attempts an exploratory inquiry to generate broad comparative implications; a systematic and confirmatory comparison based on empirical data is beyond the scope of this study. The research strategy this paper adopts is twofold. First, it primarily focuses on developing a theoretical rationale and 
illustrating that rationale through an examination of the crucial case of U.S. nuclear power policymaking. Second, this research draws relevant implications to consider with respect to Korean politics. Those implications, though not rigorously-tested, data-backed findings, still are expected to broaden our understanding of legislative-executive relations in South Korea, as well as those in the United States, and to uncover clues for better policy governance in both countries.

\section{THEORETICAL REASONING: BEYOND THE LEGISLATIVE PROCESS INTO ADMINISTRATIVE REALMS}

There is little disagreement about the trend of intense partisan conflicts and polarization in U.S. politics (Bond and Fleisher 2000; Jacobson 2013; Smith and Gamm 2013; Aldrich et al. 2013; Koger 2013; McCarty 2007; Mann and Ornstein 2006; Brownstein 2007). Party polarization has deepened everywhere, but it is especially visible in the national legislative arena. Party voting and party unity scores have consistently grown in the U.S. Senate and the House of Representatives. Inter-party distances measured by each party's issue positions have increased remarkably. Signaling this trend of polarization, congressional leaders of both parties have competed to utilize "unorthodox" legislative procedures as tactical moves to further partisan interests (Sinclair 2007). Filibusters have become near routine to the point of often failing to draw high media attention. Congress today is more hostile internally, and in its relationship with the executive branch, than in the so-called "textbook" era.

Popular questions in academic circles studying polarization have focused on how polarization has been defined, whether polarization was confined to political elites or reflected a fundamental ideological shift in American society, and what factors caused polarization among politicians and, if any, within the American electorate. Curiously, however, the effects of polarization on policy governance have generated relatively scant scholarly interest. According to one scholar, "relatively less attention ... has been paid to how this breakdown in bipartisanship has affected public policy and the routine functioning of our national government" (McCarty 2007, 223). As well as being overlooked, the question of what consequences polarization has brought to policy arenas has also failed to generate a scholarly consensus. Roughly speaking, two opposing views contest with each other: the "gridlock" school versus the "moderation" school.

Pundits belonging to the "gridlock" school charge polarization with aggravating legislative inefficiency and deepening policy stalemate (Binder 2001; Bond and 
Fleisher 2000; Hacker 2004; Dodd and Schraufnagel 2013; Hacker and Pierson 2005). Polarization makes it tougher to reach middle-of-the-road compromises and build the broad legislative coalitions needed for making new policies. In this view, gridlock becomes inevitable, especially when polarization coincides with supermajority rules. Supermajority hurdles deserve particular attention: successful passage of legislation in the U.S. lawmaking process often requires a supermajority backing and is thus essentially driven by the preferences of those pivotal actors whose support is necessary in order to overcome obstructions such as filibusters and presidential vetoes. Even a majority party with large margins of seats in the houses of Congress has a hard time pushing a policy agenda at its will. No wonder parties trapped in polarized competition typically encounter deadlock situations.

The "gridlock" argument may seem convincing in view of all of the horror stories of policymaking confusion and failure in the context of polarized fights. Hacker (2004) says that polarization impedes the passage of many policies designed to alleviate social risks. McCarty agrees that "polarization-produced gridlock forestalls the creation of new legislative enactments" $(2007,244)$. The "gridlock" thesis, however, shows only a limited part of the entire picture. Policy breakthroughs do occur from time to time. Although gridlock may accurately characterize the U.S. legislative arena in most cases, the American government has occasionally passed or changed major policies. Without those occasional successes, the contemporary American polity would not have been so adaptive and resilient in a variety of rapidly-changing environments.

Examples of policy breakthroughs abound in recent years. During the Obama presidency, U.S economic policy shifted towards neo-Keynesianism in the wake of the 2007-2008 global financial crisis. There were a series of reforms in regulatory policy. The U.S. government successfully expanded free trade. Welfare policy and immigration policy experienced substantive revisions, too, though reformers might deem those revisions far from satisfactory. Healthcare policy was fundamentally overhauled despite a lingering controversy over how to effectively implement a reform package. Now that the new Trump era has begun, the American people have been told to expect a new series of policy changes in a wide range of areas (e.g., taxes, healthcare, welfare, immigration, energy, trade, and others.)

The incompleteness or partiality of the "gridlock" thesis may give some support to the opposite views taken by the "moderation" school. According to "moderation" views, polarization does not necessarily generate policymaking difficulties, let alone a grave gridlock crisis. Some scholars from the moderation school even argue that polarization and the ensuing political conflicts may 
better serve diverse interests and facilitate coordination during the legislative process and policy governance (Mayhew 1991; Fiorina 1992; Levin and Landy 2001). Their reasoning mostly relies on a Downsian logic: polarization produces moderate politics and middle-of-the-road policy outcomes, since each side tries to appeal to the median voter and wants to avoid blame for policy stalemate. A strategy of "centrist defecting" is the best option for each party locked in polarized warfare (Downs 1957). Levin and Landy (2001) and Mayhew (2001) examined lawmaking during the Clinton presidency and found that polarized confrontation eventually induced moderate centrist coordination in policymaking. Of course, the "moderation" subscribers do not believe that centrist convergence comes automatically. Facilitative leadership exercised by party leaders is a crucial catalyst to promoting moderation in political, as well as policy, arenas, as the experiences during the Clinton presidency exemplified in the 1990 .

Plausible as it is to some degree, the "moderation" perspective also is incomplete at best. Centrist convergence may be probable when voter preferences have a symmetrical one-peak distribution, but it is less likely to occur with a skewed asymmetrical distribution or in a polarized two-peak situation. Politics in America since the 1990s does not allow us to take for granted a symmetrical one-peak distribution of voter preferences. Polarization in party competition has widened the schism between Democratic and Republican party supporters. Expressions such as "second civil war" and "culture war" may be exaggerations, but their popular common usage in the media and public discourses suggests that both Washington and the American public might have indeed become polarized to a significant extent (Brownstein 2007; Hunter 1991). Also, despite some exceptions, the usual reality of policy governance in the United States remains far from moderation and centrist convergence. Most of the policy areas are characterized by extreme tension, rigid stalemate, and governance difficulties.

In addition to offering an incomplete partial account, both the "gridlock" and "moderation" schools commonly share a critical limitation. That is, the gridlockor-moderation dichotomy narrowly confines attention to the legislative side only. Both schools provide a simplistic picture featuring legislators and the president interacting through the legislative process, and so they miss a broader range of actors and institutions (e.g., bureaucrats) mingling more complexly in legislative and non-legislative arenas. There is no denying that the legislative arena constitutes the most important playground for politicians. Americans are accustomed to the perceived centrality of Congress and the importance of legislation as a keystone tool of policy governance. Theories of congressional 
delegation and oversight mostly assume the upper hand of Congress vis-à-vis the administration (Fiorina 1977; McCubbins and Page 1987; McCubbins and Schwartz 1987). However, the substantial non-legislative policymaking authority the president and administrative agencies boldly wield display how misguided such a narrow, single-minded look at the legislative process is. The legislative arena is not the sole stage of policy governance. Legislators, the president, and administrative officials do not always operate only as part of the legislative process. They are creative enough to find various non-legislative ways to pursue their policy goals.

The president, for one, can use non-legislative direct actions such as executive orders or presidential proclamations. Legislative haggling amidst polarized conflicts motivates the president to avoid legislative headaches by acting unilaterally, bypassing legislative procedures and instead resorting to presidential direct actions. According to McCarty, "polarization provides presidents with the incentive and an excuse for circumventing Congress and governing by executive order" $(2007,224)$. Neither opting for gridlock nor moderation, the president may take unilateral action in pushing his policy agenda to avoid engaging in difficult interactions with his congressional counterparts. He has motivations and actual powers to bypass legislative routines and instead utilize presidential direct actions (Cooper 2002; Mayer 2001; Howell 2003; Gitterman 2017; Flanagan 2011). This is a reason why an exclusively single-minded focus on the legislative process could exaggerate the possibility for gridlock or moderation resulting from political polarization.

What specific ways are available for the president to take direct action? First of all, the president can resort to utilizing existing legislation as a broad legal basis for his policy initiatives instead of submitting new legislation or trying to revise existing legislation. For example, the president may push through his climatechange policy by broadly interpreting the comprehensive Environmental Policy Act and the similarly comprehensive Energy Policy Act. Both of those acts were already passed several years earlier, so the president does not have to knock on the door of Congress to pass new legislation. Opponents may protest, of course, but a shrewd president knows how to broadly interpret an existing statute to find legitimate legal grounds for his policy initiatives.

The president has another powerful tool, executive orders. Flanagan writes, "The modern Presidency has embraced the executive order as a way to further policy goals in defiance of, or unilaterally from, Congressional action" (Flanagan 2011, 2). Executive orders are "attractive to Presidents because as opposed to working with Congress they are quicker to move forward, receive less public scrutiny and attention, and can be altered later to suit a changing situation" 
(Ibid.). Presidential proclamations are another measure available. They "can be used for simply advancing goals rhetorically or signaling a shift in policy" and "can refocus the party line, bring attention to pressing issues, and pacify interested constituents by showing concern" (Ibid., 5). Moreover, the president sometimes makes the best of signing statements as "a last resort attempt to ignore or alter a law from Congress" (Ibid.). "When the President signs a law he can attach a statement that he reserves the right to direct the bureaucracy to implement the law as he sees fit. At times this can include a directive to ignore parts of the law that conflict with administrative policy" (Ibid.).

Executive unilateralism does not exclusively belong to the president. Administrative agencies significantly shape the daily lives of citizens through a myriad of regulatory reviews, rules, and orders, often on a pure bureaucratic basis with no direction or need for approval from legislators. Those bureaucratic decisions sometimes are made with no clear signals from the president. Administration bureaucrats-who, by definition, are not elected or held accountable through elections-pursue their own agenda and often claim bigger roles. They try to fully utilize their policymaking capacity especially when political polarization thwarts or delays legislative production. They know how to manage policy governance through their own initiatives with the policy tools available to them.

The executive branch's frequent bypassing of Congress and resorting to executive tools in situations of party polarization give rise to a question: why would members of Congress not more determinedly protest the administration's unilateral policymaking? They surely would be aware of the dangers of executive unilateralism. The U.S. Congress has a large number of staffers and experts working for the institution or individual members, and they should be capable of detecting unilateral administrative actions. A vigilant mass media and interest groups also never hesitate to inform the public and lawmakers of what they think are the administration's errant unilateral actions. Despite this abundance of watchdog information, why would congressional members typically refrain from stronger challenges to the administration's unilateral actions other than just occasionally filing complaints?

An answer in the literature highlights legislators' rent-seeking motivations to protect their self-interests (Fiorina 1977; McCubbins and Schwartz 1987; McCubbins and Page 1987). Much of the literature provides a stylized-and, therefore, simplistic but enlightening-portrayal of rent-seeking legislators. Neither able to lead on their own nor willing to take the blame for policy failures and gridlock, lawmakers tend to acquiescently but strategically condone the executive branch's unilateral actions and policy initiatives. This 
strategic condoning, clever lawmakers know, can bring them several benefits: (1) legislators conveniently can shirk the responsibility of making difficult, time-consuming, and exhausting policy decisions and dump it onto the administration; (2) they can avoid antagonizing those whose interests may be at stake and thereby shrewdly eschew political risks; (3) they can evade blame for policy failures or troubles often resulting from decision-making or policy implementation; and (4) they can claim political credit; first, by criticizing ex post facto whatever the alleged mistakes administrative players commit in the process of making and implementing policy decisions and, second, by proposing real or rhetorical remedies in hindsight for those mistakes. The more the executive resorts to unilateral actions, the more chances legislators would get for ex post facto intervening in executive decisions to earn political credit. In short, such politically valuable benefits as credit-claiming, blame-avoidance, and responsibility-shirking motivate lawmakers to strategically condone executive unilateralism and put up with the dishonor of being bypassed upfront in the policymaking process.

Being shrewd strategic rent-seekers, members of Congress would want to make it easy to intervene in executive actions whenever they felt it was necessary. They would want to secure the routes for prompt ex post facto involvement and for convenient credit-claiming. For this reason, they have institutionalized various instruments useful for controlling-or at least influencing-executive actions during the stage of policy implementation. For instance, the Congressional Review Act of 1996 empowers Congress to review an administrative agency's regulatory decisions and overrule them by passage of a joint resolution. The Congressional Review Act was utilized only a single time prior to 2017, but Republican lawmakers in alliance with President Trump found it convenient for negating Obama's administrative legacies and have used it more than ten times during Trump's first 100-day honeymoon period. Members of Congress have also enjoyed the time-honored authority of holding oversight hearings and conducting investigations into any executive actions made previously. Moreover, Congress has continued to enact hundreds of bills containing provisions of "legislative veto" as a powerful weapon to scrutinize and intervene in executive decisions. The practice of using legislative vetoes has not ceased even after the INS v. Chadha ruling by the Supreme Court (1983) declared them unconstitutional (Fisher 2005). In addition to these formal tools, various kinds of informal arrangements between administrative agencies and congressional committees help legislators to control executive actions on an ex post facto basis.

Equipped with so many tools available for ex post facto oversight and intervention, members of Congress have not hesitated in delegating ample 
policymaking authority to the executive branch. They have been willing to condone executive unilateralism though they sometimes have displayed disapproving gestures in a rhetorical sense. The dual presence (some may call it collusion) of legislative inaction on the side of acquiescent, condoning, and shrewdly-controlling members of Congress, and administrative activism by a unilaterally-behaving executive branch, may stir controversy from a democratic point of view. As will be discussed later, however, aside from the normative implications, this dual presence has characterized an important aspect of the American political system and somehow has contributed to facilitating policy governance.

The following section will describe the empirical case of U.S. nuclear power policy to illustrate the theoretical ideas developed in this section. The main observational points will be: first, political confrontations-a mix of turf wars, ideological clashes, and partisan rivalries-have deepened congressional difficulties in attaining significant progress with regards to nuclear power policy. Second, this situation of political conflict and legislative stalemate in Congress has encouraged the administrative side (both the president and the bureaucracy) to resort to taking unilateral actions. Third, executive unilateralism in tandem with congressional condoning has driven nuclear policy programs and, thereby, has been a crucial factor leading nuclear power policy governance.

\section{EMPIRICAL OBSERVATIONS: U.S. NUCLEAR POWER POLICY AND EXECUTIVE UNILATERALISM}

Nuclear power refers to the civilian use of nuclear technology for energy. Analysis of this policy area has relative analytical strengths: nuclear power policy is, in its applications and wide ramifications, partly economic and partly social, partly ideological and partly political, and partly technological and partly cultural. Having this complex character, it has a comparative advantage in showing the multi-dimensional interplay between legislative and executive realms, between expertise and public opinion, and between representative and non-representative elements.

In particular, nuclear power policy features both the administration's historical activism and Congress's seemingly keen interest. Thus, it offers a legitimate crucial test case for assessing how the two branches interact with each other and which side may eventually prevail-or at least take active initiatives-in policy governance. On the one side, the U.S. administration led the initial launching of nuclear energy programs in the early post-WWII era 
and still today plays an extensive and engaging role (Green and Rosenthal 1963; Hertsgaard 1983; Barkenbus 1984; Cohn 1990; Balogh 1991). There are lengthy regulatory requirements managed by administrative officials for construction and operation of nuclear reactors, for conversion and enrichment of nuclear fuel, for mining and milling of raw materials, and for R\&D and the global spread of nuclear technology. Moreover, because nuclear power generation requires huge financial costs, the administration has willingly provided direct subsidies, loan guarantees, and tax credits so that companies would venture into such capitalintensive projects. Overall, the U.S. administration has been the main engine for nuclear energy. Faced with a messy and tumultuous congressional stage, therefore, administrative actors such as the president and officials alike must have felt obliged to circumvent the legislative process and instead resorted to convenient executive tools in order to propel nuclear energy policy.

On the other hand, nuclear power policy also has attracted the attention of Congress. Being an "easy" issue to the general public, nuclear power enjoys high public salience and stirs social concern. Since legislators typically are both keen and nervous about such an "easy" issue, it tends to generate intense competition among them. Considering this, we might expect that legislators would not likely leave the nuclear power issue to someone else's discretion and passively acquiesce to the administration's unilateral policymaking. Lawmakers, according to our expectations, would attempt to be active and engaging so much so that administrative players might hardly dare to attempt unilateral actions with regards to nuclear power policy. Nuclear power thus is a "least-likely" case for the theoretical reasoning offered in the previous section, summed up in the dual presence of congressional inactiveness and executive unilateralism. Hence, if the theoretical reasoning is supported even in this "least-likely" case, we could rather confidently infer a more general pervasiveness of executive unilateralism.

When we retrospectively glanced over the sixty-plus-year history of the U.S. civilian nuclear energy program, indeed, it has been driven largely at the behest of the executive branch. Due to its national security-related importance and its immense financial burden, U.S. administrations initially monopolized its development and regulation, and later provided huge financial incentives to participating industries. After a government-sponsored takeoff of dazzling pace up to the 1970s, however, nuclear energy began a steady decline in the aftermath of the Three Mile Island accident in 1979. The Chernobyl disaster in 1986 further fanned public fears of nuclear catastrophe and dampened any effort to materialize an earlier hope for a "nuclear paradise." Then the tide turned again in the 2000s. In tandem with the growing global concern about climate change, people began to rediscover the value of nuclear power as "clean" 
energy. President George W. Bush and pro-nuclear groups pleaded for a "nuclear renaissance" as way to both cope with global warming and lessen the United States' dependence on foreign oil. Bush's successor, President Obama, followed suit. In 2010, Obama's energy secretary, Steven Chu, called for Congress to give priority to nuclear power, and the administration repeatedly affirmed loan guarantees for nuclear plants. Of course, occasional accidents such as the 2011 Fukushima meltdown, coupled with ever-growing financial burdens, did not seamlessly allow for the premature dream for a nuclear renaissance. Nevertheless, Obama appeared to have no other option but reviving nuclear power as an important part of his administration's comprehensive energy and environmental plans.

While the administration continued to be the main champion of U.S. nuclear power policy, the congressional side has been acting quite differently since the dissolution of the Joint Committee on Atomic Energy in 1977. Congress has remained rhetorically and politically clamorous during any legislative action, but basically incapable of producing substantive legislation concerning nuclear power. This situation can be attributed to the overly-broad scope of political conflict. In the early years up until the 1970s, nuclear power policymaking was characterized by a tight "iron triangle" consisting of a small numbers of legislators, bureaucrats, and industrialists. In Congress, a single joint committee, the Joint Committee on Atomic Energy, took charge of all the issues related to nuclear power. Then, beginning in the 1970s, fierce challenges began to arise to that nuclear power "iron triangle," and the scope of conflictthat is, the number of actors engaged-dramatically expanded. This historical transformation resulted from growing public concern. Deviating from its lowsalience, non-controversial status during the early years, nuclear energy policy since the 1970s has witnessed soaring public awareness and concern as a result of the anti-nuclear movement and a series of nuclear reactor accidents. As part of this breakdown of the nuclear power "iron triangle," the Joint Committee on Atomic Energy was dissolved in 1977. There followed a radical expansion of jurisdictional boundaries, with Congress dispersing jurisdictional authority over nuclear power to several committees in both chambers. In the wake of this upheaval, the nuclear energy policy circle experienced a transformation into a wide-open "issue network" featuring several turf-feuding congressional committees, competing administrative agencies, and various interest groups, including vociferously anti-nuclear power citizen groups.

There must have been many factors behind this radical expansion of the scope of conflict (Campbell 1988; Del Sesto 1980; Morone and Woodhouse 1989; Jasper 1990; Lim 2012). Partisan fighting especially seems to have mattered. 
With each party fiercely competing to appeal to American voters over the increasingly salient and controversial issue of nuclear power, Democratic and Republican lawmakers alike must have felt pressured to jump into the issue at every available opportunity. They would want to take actions at every stage of the legislative process-sponsoring bills, claiming committee jurisdiction, taking positions in committee deliberations, making remarks during floor debates, and submitting amendments. Indeed, there have been an enormous amount of these sorts of activities undertaken by an exceptionally large number of congressional members from both parties on the issues of nuclear energy. Party competition, particularly in a polarized form, has been at work behind all this excessive broadening of the scope of conflict. However, party rivalry constituted only a part of the story. A host of other political factors, including ideological clashes, district interests, industrial connections, public opinion, and mere turf conflicts, also played roles in attracting the attention of an exceptionally large number of congressional members to nuclear power issues (Jasper 1990; Lim 2012). Nuclear power policy took on such complexity, as previously mentioned, that a combination of various factors worked to broaden the scope of conflict in Congress to an extraordinary extent.

A congressional scene overcrowded by clamorous lawmakers opened the door to confusion, inefficiency, and inaction. As far too many contradictory opinions were expressed, Congress became unable to reach collective decisions and produce legislation in a timely fashion. Concomitant with a dramatic broadening of the scope of conflict, nuclear power programs entered a plummeting downward cycle. Signs of trouble had begun to emerge already in the 1970s, but it was in the 1980 s that the public downfall of nuclear power became so striking that even nuclear industry officials publicly admitted it and desperately struggled to seek a way out of the dead end (Campbell 1988; Morone and Woodhouse 1989; Komanoff 1991). No new nuclear power plants were ordered until recently, and there have been more than a hundred cancellations of nuclear plants that had previously been licensed to be built (Nealey 1990). An initially rosy picture for the future of nuclear power shattered badly.

The wrecking of the U.S. nuclear power program was certainly not a result of the political situation alone. Several stumbling blocks hampered the growth of the civilian nuclear power industry. Unexpected reactor-related accidents, tireless opposition by anti-nuclear groups, the slow pace of technological developments, inefficient management of the industry, and a drop in the demand for electricity, all of these were unfavorable and demoralizing to the industry. However, a dramatic broadening of the scope of conflict also must take a big share of the responsibility. The presence of too many players in the legislative 
process intensified conflicts and aggravated confusion about which direction nuclear power policy should take. Policy progress is hard to come by when there are too many clamorous legislators in an environment of an excessively expanded scope of conflict.

After the long decline, nuclear power programs finally received a new push during the George W. Bush presidency. His energy policy plan announced in May 2001 called for the streamlining of the lengthy licensing and regulatory processes, warming up the idea of a "nuclear renaissance" (Boyd 2010, 11). The Nuclear Power 2010 Program was launched in 2002 as an effort to construct new nuclear power plants. Inheriting Bush's initiative, Obama, despite fundamental disagreements with the Bush administration on a host of issues, had a similarly favorable attitude toward nuclear energy and cherished a vision of a nuclear renaissance. To make manifest Obama's pro-nuclear stance, Energy Secretary Steven Chu appointed mostly pro-nuclear members to the Blue Ribbon Commission on America's Nuclear Future, which was tasked with making recommendations on a solution to managing spent nuclear fuel and high-level radioactive waste storage (Boyd 2010, 11). In the Fiscal Year 2011 budget request, the U.S. Department of Energy (DOE) proposed $\$ 36$ billion in federal loan guarantees for the nuclear industry, on top of $\$ 18.5$ billion already budgeted, for a total of $\$ 54.5$ billion in spending (Clayton, 2010).

Undoubtedly, "nuclear energy form[ed] a crucial component of President Obama's climate action plan" (Gerhardt 2013). In February 2014, Peter Lyons, the DOE's assistant secretary, reiterated the administration's endorsement of nuclear power plants as essential to reaching carbon reduction goals (Krancer 2014). In this more favorable atmosphere, the nation's first new nuclear reactors in more than 30 years received federal government loan guarantees (Neuhauser 2014). The Obama administration's goal was ambitious: "[DOE Secretary] Moniz said the Vogtle [nuclear power] project was not only a major milestone in the Administration's commitment to jumpstart the US nuclear power industry, it is also an important part of our all-of-the-above approach to American energy as we move toward a low-carbon energy future" (Mufson 2014).

The clear pro-nuclear stance of both the Bush and Obama administrations marked a contrast to what was happening in a disoriented and ambivalent legislative branch. What explains the pro-nuclear efforts of these administrations? Not a single factor, but a mix of economic, environmental, and strategic factors taken together seemed to have made the difference. Once built, nuclear plants can produce electricity at relatively low and stable rates; however, nuclear power during the construction stage is much more costly than natural gas or oil. The economic merits thus explain only a part of the story. Nuclear 
power is emissions-free and may be effective against climate change, but many environmentalists oppose nuclear power for its vulnerability to accidents of devastating consequences, and so any environmental merits also provide only a partial explanation. What appears more important is the strategic value of nuclear power in terms of energy independence from foreign oil-exporting countries and its potential linkage to the enhancement of a nuclear weapons arsenal and its global influence (Gerhardt 2013).

A combination of these economic, environmental, and strategic merits must have motivated actors in the executive branch, particularly the president, to push nuclear power policy. Those executive actors had done so even at the risk of antagonizing legislators by bypassing them and going it alone using tools available to administration officials. Obama's executive unilateralism took several forms. As with his predecessors, Obama above all refrained from regularly resorting to introducing new legislation. The past sixty-plus years have witnessed the passages of only several major pieces of legislation related to nuclear energy: the Atomic Energy Act of 1954, the Energy Reorganization Act of 1974, the Uranium Mill Tailings Radiation Control Act of 1978, the Nuclear Waste Policy Act of 1982, the Energy Policy Act of 1992, and the Energy Policy Act of 2005. The Obama era failed to produce a single piece of major nuclear legislation; Obama preferred a strategy of broadly interpreting the existing 2005 Energy Policy Act rather than trying to convince lawmakers to pass new legislation. For instance, his decision to issue loan guarantees for the nuclear industry found its legal justification in the 2005 law.

Obama also stubbornly stuck to his "plan to use executive powers ... without congressional input" (Plumer 2013). His administration relied on the implementation rules and regulatory decisions of the Department of Energy and the Nuclear Regulatory Commission in order to boost nuclear energy production and bring about a revival of nuclear power. The main policy means were funding, loan guarantees, licensing, and advanced research, all of which were under the authority of the administration and required no congressional endorsements. Loan guarantees were particularly convenient because they were not a part of government appropriations and called for no congressional involvement or approval.

Obama was especially skillful in discouraging congressional meddling. His pro-nuclear stance above all may have been a political strategy to adopt a Republican idea, woo Republicans with their own pet project, and thus preempt their critical (re)actions. In February 2010, "Obama told reporter that his embrace of nuclear power is part of an effort to adopt some Republican ideas on energy, adding that he remains an eternal optimist about bipartisanship" 
(Sheppard 2010). His approach was actually successful in quieting congressional challenges. There was little opposition from Congress: "Support for nuclear is not a Republican issue alone ... In fact, several of the proposed new reactors are in districts or near districts represented by Democrats and are strongly supported by them" (Boyd 2010, 11). Even though liberal Democrats were never friends of nuclear power itself, they refrained from launching all-out attacks. Given the generally favorable opinions of the public, and fully aware that they themselves were unable to find a better alternative, members of Congress probably thought that passively acquiescing to the administration's initiatives was the best strategy (Boyd 2010).

Moreover, a cautious, indirect "stealth" approach was conducive to the lack of strong congressional challenges to Obama's initiatives. He typically refrained from coming forward to take center stage in support of nuclear power. Instead, his secretaries and high-ranking officials played the main roles in taking concrete actions to affirm governmental support for nuclear energy and preach the importance of nuclear power as "clean" energy. For example, Obama did not specifically mention nuclear power in the 2014 State of the Union Address that he delivered in front of congressional members. Then, less than a couple of weeks later, DOE Assistant Secretary Peter Lyons clarified the administration's support for nuclear power (Krancer 2014). Following Lyons' remarks, the DOE on February 19, 2014, approved $\$ 6.5$ billion in loan guarantees for the Vogtle nuclear project in Georgia. DOE Secretary Ernest Moniz also repeated the administration's pro-nuclear stance saying, "the President wants to make clear that he sees nuclear energy as part of his carbon-free portfolio" (Morello 2014). Obama shrewdly spoke through other government officials to send a positive signal about nuclear power programs; that way, he was able to sidestep congressional antagonisms and any potential legislative headaches.

The penchant for unilateral executive actions may be attributable to various factors but, in a fundamental sense, the contentious or even hostile political climate in recent years must have critically mattered. However friendly with Congress a president might be, he would not want to struggle in vain through a perilous legislative process filled with partisan-motivated obstructions, delays, and stalemates. Even a leader blessed with effectively persuasive skills and strong willpower would find it a terribly daunting task to pass his policy agenda through an increasingly polarized legislative process marked by tough legislative fights. The following observation by Washington Post journalist Dan Balz is suggestive in this regard:

"During the 2012 campaign, ... [sympathetic voters in focus groups] 
wondered why Obama lacked whatever LBJ had. Why couldn't Obama make the machinery work better? Why couldn't he cajole and threaten and sweet talk and bully the Congress into action the way Johnson had? Obama is a far different person than Johnson. He is cool, cerebral and detached. Johnson was the earthy, insecure political seducer. Still, it is questionable whether even LBJ could be LBJ in today's polarized political climate. Could he really have found a way to bring tea party Republicans to the bargaining table with any more success than has Obama? Even some who have studied Johnson's presidency wonder" (2014).

The case of U.S. nuclear power policy, as this section has shown, illustratively supports the theoretical reasoning established in the previous section. Recent U.S. presidents and administration officials have adopted executive unilateralism and have bypassed a conflict-ridden Congress that features an exceptionally broad scope of conflict in order to promote nuclear power programs. Unilateral executive actions, not legislation, have been the main policy instruments. Members of Congress, however, did not seriously challenge the administration's going it alone, implying that they were making rent-seeking calculations. Given that nuclear power issues generated a lot of public attention and concern, members of Congress were least-likely to be expected to acquiesce to the executive's unilateral actions on those issues. Even this least-likely case crucially affirms the pervasiveness of executive unilateralism as a policy tool. Here we see a general prevalence of executive unilateralism in tandem with strategic, covert congressional behaviors of condoning acquiescence. Although a single case does not allow for the strongest of generalizations, this case of nuclear power policy is highly suggestive.

\section{COMPARATIVE IMPLICATIONS}

\section{EXECUTIVE UNILATERALISM, A BLOW TO DEMOCRACY?}

It may seem ironic if political intensity and vigor during the legislative process, by bringing a state of conflict and gridlock, undermine the keystone representative institution and instead bolster the administrative state. As the case of U.S. nuclear power politicking demonstrates, political confrontations and obstructions in Congress tend to generate legislative inaction and gridlock and prompt unilateral policy activism by the executive branch. Administrative actors want to avoid pursuing frustrating legislative routes and instead resort to 
using more convenient executive policy measures. If such situations continue, the upshot will be a lasting institutional power imbalance to the advantage of the administration. This might be a warning signal to those who are concerned about such principles of democracy as separation of powers and checks and balances. Here we are reminded of President Nixon, who adamantly pushed his policy agenda through against a recalcitrant Congress and fostered an extreme form of executive dominance and institutional imperialism to the point of the criminality of Watergate.

Ironical as it may be, however, executive unilateralism demands a more nuanced evaluation. It may not be something to be condemned unconditionally. From the viewpoint of supporting principles of democratic government, it certainly deserves harsh criticisms, but if we prioritize policy governance, we may take a more sympathetic view. U.S. presidents and administrations have often managed to make policy progress through the use of unilateral policy tools, as the case of nuclear energy policymaking attests. Without those active efforts by the executive to promote policy goals through non-legislative policy measures, there might have been dismally few policy achievements. The democratic principles of representation and institutional balance are surely important, and unilateral discretion by administrative actors undoubtedly undermines those principles; however, values related to policy governance, such as efficiency, effectiveness, timeliness, and innovativeness, also have undeniable importance. We need to keep these points in mind when evaluating executive unilateralism.

The legislative and executive branches are tacit strategic partners for policy governance. If one branch has trouble in producing necessary policy results, the other could come forward to fill the vacuum through whatever means are politically available. U.S. members of Congress, aware of their institution's limitations in making policy progress in an acceptable timeframe, have largely acquiesced to the executive branch's tactic of taking unilateral action. If congressional leaders find a specific executive decision unacceptable or problematic, they can resort to using oversight instruments ex post facto, such as hearings, investigations, legislative vetoes, and congressional reviews. Administration officials, in turn, tend not to seriously defy those ex post facto measures of control by Congress. In particular, the executive has not objected outright to provisions of legislative vetoes even after the 1983 Supreme Court decision in INS v. Chadha declared the practice of legislative veto unconstitutional. Also, administration officials have not challenged the Congressional Review Act that empowered Congress to nullify an administrative decision ex post facto.

Through this practice of mutual strategic connivance, the U.S. legislative and 
executive branches have worked together for the purposes of policy governance. They are "stealth" partners in the sense that their mutually-complementary functions are neither explicit nor clearly intended. Executive unilateralism in certain policy areas, therefore, needs to be understood and evaluated in tandem with an environment of partisan legislative gridlock and strategic acquiescence by lawmakers. A fuller picture of policy governance requires a more far-sighted and broader look into both legislative and executive policymaking contexts.

\section{HOW IS THE SOUTH KOREAN CASE DIFFERENT FROM THE U.S. CASE?}

Comparatively speaking, the United States' long tradition of inter-branch balance provides a "least-likely" case for the theoretical reasoning offered in this paper. The United States boasts of an influential legislature and a sturdy checks and balances system that, at first glance, are incompatible with the notion of executive unilateralism driving policy governance. By contrast, South Korea appears to have more favorable conditions for executive unilateralism. Political conditions in the country, such as a strong administrative apparatus, the president's dominance over administrative agencies, and the frailty of the legislature's political and institutional leverage in controlling administrative policymaking, may lead to the expectation that Korea's executive actors are in a position to freely bypass the legislative process and unilaterally lead policy governance.

However, contrary to this first-glance expectation, policymaking in South Korea in recent years has featured inter-branch deadlock and chronic governance failures. This gloomy situation in Korea stands in marked contrast to the U.S. case, which has shown occasional policy progress led by a unilaterallyacting president and administrative agencies. Putting aside the current Moon Jae-in presidency, which is enjoying a honeymoon period, South Korea recently has suffered comparatively severe and persistent governance difficulties. Gridlock was not confined to the legislative process alone; it also characterized overall legislative-executive relations, and policy governance all-in-all has been in shambles. Efforts by recent Korean presidents and administrative agencies to act unilaterally to achieve certain policy goals typically have led to vehement criticism from their legislative counterparts. The ensuing inter-branch conflicts have grown so intensive and extensive that the whole policymaking system often has been paralyzed. Certainly, this portrayal is a crude generalization. Not every single policy yielded such a gloomy picture. Still, roughly speaking, few in South Korea today fail to perceive the governance troubles that are seriously and chronically bogging down the process of producing and implementing policies. 
The dismal perception of the public in this regard has been unmistakably clear in all of the public opinions polls available.

What explains this counter-intuitive difference between the two countries? Both share broad structural similarities: separation-of-powers, a presidential system, a first-past-the-post single-member district election for choosing legislators, supermajoritarian legislative processes, and the frequent emergence of divided government. The two countries are, moreover, experiencing similar environments of political polarization. Despite these similarities, the United States is characterized by occasional policy progress largely led by an active and unilaterally-acting executive, while South Korea fails to achieve similar progress and remains trapped in overall governance stalemate, though the fledgling Moon Jae-in government is not taken into account as part of this research.

This contrast can be explained in terms of strategic thinking and political calculations, or a lack thereof, on the part of both legislators and executive actors. As theorized in an early section, U.S. members of Congress have willingly, though tacitly, acquiesced to the executive branch's policy unilateralism for their own benefits. Congressional leaders, by doing so, can shirk responsibility for making difficult policy decisions and can avoid antagonizing those whose interests are at stake. Members of Congress also can evade blame for policy failures. Moreover, legislators can claim political credit by criticizing any missteps the administration takes in its policy decisions and actions. It is no wonder lawmakers have retained various instruments for ex post facto oversight of administrative decisions. This kind of strategic thinking and political calculations motivate legislators to condone executive unilateralism in certain policy areas, though they may evince some rhetorical concerns and complaints about their branch's belittlement. Consequently, the U.S. administration has been able to resort to the shrewd usage of executive policy tools to strategically garner occasional achievements in the policy areas that it deems important.

By contrast, the South Korean political landscape allows little space for such strategic thinking or calculations. Korean politicians have acted as nervous followers of partisan solidarity and factional discipline. If they breach party unity and cross party lines, they are destined to face severe formal and informal penalties from the party leadership. Korean politicians therefore move en masse according to their party identification. This rigid and suppressive collectivist atmosphere has prevented individual-level strategic thinking and rational choice among legislators from being put into action. As all major political activities are driven by partisanship or factional motivations, total war-like across-the-board confrontations have stifled both the legislative process and legislative-executive relations. This kind of full-scale political warfare between collectivist blocs in the 
legislature leaves little room for strategic acquiescence by lawmakers or strategic policy unilateralism by administration officials.

In recent years, there were a few good chances to alter this situation, but every time the now-ousted President Park Geun-hye and her party loyalists played the role of spoiler. In the first instance of such a lost opportunity, in June 2015, President Park vetoed a revision to the National Assembly Act. The revision bill would have enabled Korean lawmakers to seek changes to government ordinances that appeared to undermine existing laws (Cho 2015). With this revision, lawmakers would have been equipped with an effective institutional tool for ex post facto intervention in administrative decisions and, therefore, could have rather easily acquiesced to and condoned unilateral executive actions. However, Park did not understand the strategic dynamics and flatly refused the revision bill. A belief that the revision might encroach on her executive power made her furious, and she harshly denounced politicians on both sides of the aisle for not blocking the bill. She even inveighed against the chief whip of her own party, Yoo Seung-min: "Park bombarded Yoo, holding him responsible for succumbing to the opposition party's demand to pass the bill and casting a slur against him for being critical of her major policies" (Ibid.). Park went to the extreme of calling Yoo a "traitor who should be voted out of office during a nationally televised Cabinet meeting" (Jeong 2015). Moon Jae-in, who was then opposition leader and now is the president, lamented: "Politics has vanished, and only the president's stubbornness and obstinacy remain" (Cho 2015).

Park again wielded her veto power in 2016, marking the second lost opportunity. In May 2016, she rejected a parliamentary hearing bill that would have allowed standing committees to call for public hearings to deliberate and investigate on any agenda item considered important (Lee 2016). The bill would have bolstered the leverage of the National Assembly on policy issues in general and administrative actions in particular. Frequent committee hearings would have been especially useful for overseeing and, if necessary, fixing administrative decisions ex post facto. With this new upgraded power in hand, lawmakers would have felt less uncomfortable in delegating substantial policymaking authority to the administration and also in covertly condoning executive unilateralism. Park, unfortunately, did not see the strategic side of these potential mutual benefits and stubbornly clung to a misplaced concern that the bill would be used as a political tool to paralyze the executive branch. Some National Assembly members of Park's own ruling party undoubtedly disagreed with her, but the political persecution Yoo Seung-min had experienced sent a chilling lesson to the rank-and-file not to stray too far from the party line.

The two misjudgments by former President Park took away any chance to 
empower National Assembly members with adequate oversight authority and the tools they needed to carry out impactful oversight, effectively dampening their motivation to strategically condone executive unilateralism. If National Assembly members had sufficient powers to oversee the administration, they would have been better able to act strategically and allow a bigger discretionary space for the executive branch. Along with rigid collectivist party discipline, an insufficient and ineffective legislative oversight capability has prevented Korean politicians from acting more strategically. The absence in Korea of tacit strategic arrangements-let alone explicit agreements-between legislative and executive officials is unfortunate for the sake of policy governance. In the United States, executive unilateralism has been a natural recipe for overcoming overly confrontational and confusing inter-branch interactions and chronic gridlock in policy governance. The persistence-even aggravation-of governance woes in South Korea suggests that Korean political party members and government officials can learn a comparative lesson from the United States. Politicians need to prioritize strategic thinking and rational calculations over rigid partisan groupthink in order to achieve the vital goal of productive policy governance.

\section{CONCLUSION}

Executive unilateralism by itself will never win acclaim from legislators, the public, or the media, but it deserves a more balanced evaluation in an era of increasingly helpless lawmakers hamstrung by ossified partisan gridlock. Unilateral actions by executive branch officials can propel policy progress and revitalize policy governance. Executive unilateralism for better policy governance is justifiable especially when legislators who are stuck in a political deadlock fail to produce legislation. The justification for executive unilateralism is even stronger when lawmakers, who are neither able to govern by themselves nor willing to take the blame for policy failures, strategically acquiesce to the executive branch's policy initiatives. This paper examined the case of U.S. nuclear power policy in which U.S. administrative actors, including the president, resorted to the use of executive policy tools in order to bypass a gridlock-prone Congress. Members of Congress, in gestures of strategic condoning, did not seriously challenge those unilateral executive actions concerning nuclear power policy.

Facilitating policy governance in an era of legislative gridlock by means of executive unilateralism is not easy. It requires strategic calculations on the part of both lawmakers and executive officials. Legislators can benefit from strategically 
condoning executive policymaking and then focusing on ex post facto oversight and intervention. Administration officials need to act strategically by accepting the legislature's power to intervene in those unilateral decisions after the fact. This kind of mutual strategic understanding helps to achieve policy progress and to sustain policy governance. South Korean politicians are advised to note these strategic dynamics. If Korea's National Assembly members enjoy sufficient authority to intervene in administrative decisions and earn political credit for such interventions, they might be willing to delegate adequate policymaking power to the executive branch to act unilaterally. The vetoes of ex-President Park against legislation that would have expanded the National Assembly's ability to amend administrative decisions and hold committee hearings was deplorable, in this sense. A call for reassessing executive unilateralism from a strategic standpoint as a way to secure better policy governance could grow louder in proportion to the increasing turmoil and stalemate in the legislative arena.

\section{REFERENCES}

Aldrich, John H., Brittany N. Perry, and David W. Rohde. 2013. "Richard Fenno's Theory of Congressional Committees and the Partisan Polarization of the House." In Lawrence C. Dodd and Bruce I. Oppenheimer eds., Congress Reconsidered. 10th Edition. Washington, D.C.: CQ Press, 193-220.

Balogh, Brian. 1991. Chain Reaction: Expert Debate and Public Participation in American Commercial Nuclear Power, 1945-1975. Cambridge: Cambridge University Press.

Balz, Dan. 2014. "Obama and LBJ: Measuring the Current President against the Past One's Legacy." The Washington Post (April 13). Accessed at https://www.washingtonpost.com/politics/obamaand-lbj-measuring-the-current-president-against-the-past-oneslegacy/2014/04/12/672718fe-c258-11e3-bcec-b71ee10egbc3_story. html?utm_term $=.2$ fe2a5644243 (August 7,2017 ).

Barkenbus, Jack N. 1984. "Nuclear Power and Government Structure: The Divergent Paths of the U.S. and France." Social Science Quarterly 65(1), 37-47.

Baumgarter, Frank R., and Bryan D. Jones. 1993. Agendas and Instability in American Politics. Chicago, IL: The University of Chicago Press. . 1991. "Agenda Dynamics and Policy Subsystems." Journal of Politics 53(4), 1044-1074. 
Binder, Sarah A. 2001. "Congress, the Executive, and the Production of Public Policy: United We Govern?” In Lawrence C. Dodd and Bruce I. Oppenheimer eds., Congress Reconsidered. 7th Edition. Washington, D.C.: CQ Press, 293-313.

Bond, Jon R. and Richard Fleisher eds., 2000. Polarized Politics: Congress and the President in a Partisan Era. Washington, D.C.: CQ Press.

Boyd, Michele. 2010. Is There a Nuclear Revival in the United States? Report for the Heinrich Boll Stiftung North America.

Brownstein, Ronald. 2007. The Second Civil War: How Extreme Partisanship Has Paralyzed Washington and Polarized America. New York: The Penguin Press.

Campbell, John. 1988. Collapse of an Industry: Nuclear Power and the Contradictions of U.S. Policy. Ithaca, NY: Cornell University Press.

Cho, Chung-un. 2015. "President's Veto Roils Assembly." The Korea Herald (June 25). Accessed at http://www.koreaherald.com/view. php?ud=20150625000669\&ACE_SEARCH=1 (January 17, 2017).

Cohn, Steve. 1990. "The Political Economy of Nuclear Power: The Rise and Fall of an Official Technology.” Journal of Economic Issues 24(3), 781811.

Cooper, Phillip J. 2002. By Order of the President: The Use and Abuse of Executive Direct Action. Lawrence, KS: University Press of Kansas.

Clayton, Mark. 2010. "Obama's Nuclear Power Policy: A Study in Contradictions?” The Christian Science Monitor (February 4). Accessed at https://www.csmonitor.com/USA/2010/0204/Obama-s-nuclearpower-policy-a-study-in-contradictions (January 17, 2017).

Del Sesto, Steven L. 1980. "Conflicting Ideologies of Nuclear Power: Congressional Testimony on Nuclear Reactor Safety.” Public Policy 28, 39-70.

Dodd, Lawrence C. and Scot Schraufnagel. 2013. "Party Polarization and Policy Productivity in Congress: From Harding to Obama." In Lawrence C. Dodd and Bruce I. Oppenheimer eds., Congress Reconsidered. 10th Edition. Washington, D.C.: CQ Press, 437-463.

Downs, Anthony. 1957. An Economic Theory of Democracy. New York: Harper \& Row.

Ferejohn, John A. 1987. “The Structure of Agency Decision Processes.” In Mathew D. McCubbins and Terry Sullivan eds., Congress: Structure and Policy. Cambridge, UK: Cambridge University Press, 441-461.

Fiorina, Morris P. 1977. Congress; Keystone of the Washington Establishment. New Haven, CT: Yale University Press. 
. 1992. Divided Government. New York: Macmillan.

Fisher, Louis. 2005. "Legislative Vetoes after Chadha.” CRS Report (May 2).

Flanagan, Sean. 2011. "The Administrative Power of the President: Environment Policy from Clinton to Obama." The Fellows Review 20102011. Center for the Study of the Presidency \& Congress. http://cspc. nonprofitsoapbox.com/publications/presidential-fellows-works/thefellows-review-2011-2012/622-text-of-the-fellows-review-2010-2011 (January 15, 2017).

Foreman, Christopher H. 1988. Signals from the Hill: Congressional Oversight and the Challenge of Social Regulation. New Haven, CT: Yale University Press.

Gerhardt, Tina. 2013. "Obama's Climate Action Plan: Nuclear Energy?" Huffington Post (July 11). Accessed at http://www.huffingtonpost. com/tina-gerhardt/obamas-climate-action-plan4_b_3546999.html (January 18, 2017).

Ginsberg, Benjamin and Martin Shefter. 1990. Politics by Other Means: The Declining Importance of Elections in America. New York: Basic Books.

Gitterman, Daniel. 2017. Calling the Shots: The President, Executive Orders, and Public Policy. Washington, D.C.: Brookings Institution Press.

Green, Harold P. and Alan Rosenthal. 1963. Government of the Atom: The Integration of Powers. New York: Atherton Press.

Hacker, Jacob S. 2004. "Privatizing Risk without Privatizing the Welfare State: The Hidden Politics of Social Policy Retrenchment in the United States." American Political Science Review 98(2), 243-260.

Hacker, Jacob S. and Paul Pierson. 2005. Off Center: The Republican Revolution and the Erosion of American Democracy. New Haven, CT: Yale University Press.

Harris, Richard A. 1989. “A Decade of Reform.” In Richard A. Harris and Sidney M. Milkis eds., Remaking American Politics. Boulder, Colorado: Westview Press, 3-24.

Heclo, Hugh. 1978. "Issue Networks and the Executive Establishment." In Anthony King ed., The New American Political System. Washington, D.C.: American Enterprise Institute, 87-124.

Hertsgaard, Mark. 1983. Nuclear Inc.: The Men and Money behind Nuclear Energy. New York: Pantheon Books.

Howell, William G. 2003. Power without Persuasion: The Politics of Direct Presidential Action. Princeton, NJ: Princeton University Press.

Hunter, James Davison. 1991. Culture Wars: The Struggle to Define America. New York: Basic Books. 
Jacobson, Gary C. 2013. "Partisanship, Money, and Competition: Elections and the Transformation of Congress Since the 1970s." In Lawrence C. Dodd and Bruce I. Oppenheimer eds., Congress Reconsidered. 10th Edition. Washington, D.C.: CQ Press, 117-144.

Jasper, James M. 1990. Nuclear Politics: Energy and the State in the U.S., Sweden, and France. Princeton, NJ: Princeton University Press.

Jeong, Hunny. 2015. "Saenuri Floor Leader Quits under Pressure." The Korea Herald (July 8). Accessed at http://www.koreaherald.com/view. php?ud=20150708000865\&ACE_SEARCH=1 (January 17, 2017).

Jones, Bryan D., Frank R. Baumgartner and Jeffrey C. Talbert. 1993. "The Destruction of Issue Monopolies in Congress." American Political Science Review 87(3), 657-671.

King, David C. 1994. "The Nature of Congressional Committee Jurisdictions." American Political Science Review 88(1), 48-62.

Koger, Gregory. 2013. "Filibustering and Parties in the Modern Senate." In Lawrence C. Dodd and Bruce I. Oppenheimer eds., Congress Reconsidered. 10th Edition. Washington, D.C.: CQ Press. 221-236.

Komanoff, Charles. 1991. "10 Blows that Stopped Nuclear Power." The Electricity Journal 4(1), 18-25.

Krancer, Michael. 2014. "Obama Energy Official: Nuclear Plants Essential to Our Carbon Reduction Goals.” Forbes (February 12). Accessed at https://www.forbes.com/sites/michaelkrancer/2014/o2/12/obamaenergy-official-nuclear-plants-essential-to-our-carbon-reductiongoals/\#7ab944b61294 (January 15, 2017).

Lee, Hyung-jeong. 2016. "Park Vetoes Hearing Bill." The Korea Herald (May 27). Accessed at http://www.koreaherald.com/view. php?ud=20160527000665\&ACE_SEARCH=1 (January 17, 2017).

Levin, Martin A. and Marc K. Landy. 2001. "Durability and Change." In Martin A. Levin, Marc K. Landy and Martin Shapiro eds., Seeking the Center: Politics and Policymaking at the New Century. Washington, D.C.: Georgetown University Press, 3-32.

Lim, Seong-Ho. 2012. "Narrow Congressional Jurisdictional Boundaries, Closed Policymaking Process, and Crisis-Bound Governance: U.S. Nuclear Power Policy in Early Years and Its Implications." Oughtopia: The Journal of Social Paradigm Studies 27(2), 5-36.

Lowi, Theodore J. 1990. "Distribution, Regulation, Redistribution: The Function of Government." In Pietro S. Nivola and David H. Rosenbloom eds., Classic Readings in American Politics. 2nd Edition. New York: St. Martin's Press, 512-523. 
Mann, Thomas E. and Norman J. Ornstein. 2006. The Broken Branch: How Congress Is Failing America and How to Get It Back on Track. Oxford, UK: Oxford University Press.

Mayer, Kenneth R. 2001. With the Stroke of a Pen: Executive Orders and Presidential Power. Princeton, NJ: Princeton University Press.

Mayhew, David R. 1991. Divided We Govern: Party Control, Lawmaking, and Investigation, 1946-199o. New Haven, CT: Yale University Press. 2001. "Much Huffing and Puffing, Little Change." In Martin A. Levin, Marc K. Landy and Martin Shapiro eds., Seeking the Center: Politics and Policymaking at the New Century. Washington, D.C.: Georgetown University Press, 339-349.

McCarty, Nolan. 2007. "The Policy Effects of Political Polarization.” In Paul Pierson and Theda Skocpol eds., The Transformation of American Politics. Princeton, NJ: Princeton University Press, 223-255.

McCubbins, Mathew D. and Talbot Page. 1987. "A Theory of Congressional Delegation." In Mathew D. McCubbins and Terry Sullivan eds., Congress: Structure and Policy. Cambridge, UK: Cambridge University Press, 409-425.

McCubbins, Mathew D. and Thomas Schwartz. 1987. "Congressional Oversight Overlooked: Police Patrols versus Fire Alarms.” In Mathew D. McCubbins and Terry Sullivan eds., Congress: Structure and Policy. Cambridge, UK: Cambridge University Press, 426-440.

Morello, Lauren. 2014. "US Energy Agency Gives Boost to Nuclear Project." Nature: International Weekly Journal of Science (February 20). Accessed at https://www.nature.com/news/us-energy-agency-givesboost-to-nuclear-project-1.14751 (January 18, 2017).

Morone, Joseph G. and Edward J. Woodhouse. 1989. The Demise of Nuclear Energy? New Haven, CT: Yale University Press.

Mufson, Steven. 2014. "Why Is the Obama Administration Using Taxpayer Money to Back a Nuclear Plant That's Already Being Built.” The Washington Post (February 21). Accessed at https://www. washingtonpost.com/news/wonk/wp/2014/02/21/why-is-the-obamaadministration-using-taxpayer-money-to-back-a-nuclear-plant-thatsalready-being-built/?utm_term=.85c86fe2497d (January 16, 2017).

Nealey, Stanley M. 1990. Nuclear Power Development: Prospects in the 1990 . Columbus, OH: Battelle Press.

Neuhauser, Alan. 2014. "Despite New Plants, Nuclear Future Still Decades Away." U.S. News \& World Report (February 21). Accessed at https:// www.usnews.com/news/articles/2014/02/21/energy-dept-backs-new- 
nuke-plants-but-nuclear-future-still-decades-away (January 16, 2017). Plumer, Brad. 2013. "Obama Is Announcing Major New Climate Plans Tuesday." The Washington Post (June 23). Accessed at https:// www.washingtonpost.com/news/wonk/wp/2013/o6/23/obamais-announcing-new-climate-actions-tuesday-this-chart-explainswhy/?utm_term $=.66 f 74 f 7 b 04 c 7$ (January 16, 2017).

Ripley, Randall B. and Grace A. Franklin. 1987. Congress, the Bureaucracy, and Public Policy. 4th Edition. Pacific Grove, CA: Brooks/Cole Publishing.

Salisbury, Robert H. 1990. "The Paradox of Interest Groups in WashingtonMore Groups, Less Clout." In Anthony King ed., The New American Political System. 2nd Edition. Washington, D.C.: The AEI Press, 203229.

Schattschneider, E. E. 1960. The Semi-Sovereign People. New York: Holt, Rinehart, and Winston.

Sheppard, Kate. 2010. "GOP: Obama "Anti-Nuclear"." Mother Jones (February 9). Accessed at http://www.motherjones.com/politics/2010/02/thinkobamas-got-big-nuke-plans-check-out-gop/ (January 15, 2017).

Sinclair, Barbara. 2007. Unorthodox Lawmaking: New Legislative Processes in the U.S. Congress. 3rd Edition. Washington, D.C.: CQ Press.

Smith, Steven S. and Gerald Gamm. 2013. "The Dynamics of Party Government in Congress.” In Lawrence C. Dodd and Bruce I. Oppenheimer eds., Congress Reconsidered. 1oth Edition. Washington, D.C.: CQ Press, 167-192.

Somsel, Joseph. 2012. "Obama's War on Nuclear Power." American Thinker (October 13). Accessed at http://www.americanthinker.com/ articles/2012/10/obamas_war_on_nuclear_power.html (January 16, 2017).

Uslaner, Eric M. 1989. Shale Barrel Politics: Energy and Legislative Leadership. Stanford, CA: Stanford University Press. 